\title{
ХУДОЖНІ ВИМІРИ БОЖЕСТВЕННОГО І ДЕМОНІЧНОГО В РОМАНІ ОЛЕСЯ ІЛЬЧЕНКА «МІСТО 3 ХИМЕРАМИ»
}

У статті досліджено роман Олеся Ільченка «Місто з химерами» 3 погляду репрезентації в ньому понять божественного й демонічного. Художня структура твору моделюється завдяки кільком базовим змістовим рівням, основаним на низиі архетипних образів $i$ мотивів, які стають предметом спеціального зацікавлення в роботі. Висвітлено специфіку художньої трансформації культурних констант храму, дому, міста, а також числової символіки; досліджено характер метафоризаиії міського простору як дому, космосу, організму.

Ключові слова: художня структура, символ, архетип, культура.

Божественне і демонічне як втілення Добра і Зла належать до змістових універсалій світової літератури. На сучасному етапі розвитку національного письменства ці глобальні константи людської свідомості продовжують втілюватися на сторінках художніх творів, їх змістове наповнення варіюється, демонструючи свою невичерпність. Містичні елементи органічно входять до структури історичного роману, слугуючи образним втіленням складних суспільних процесів, епохальних світоглядних зрушень. Саме цим художнім завданням мотивоване використання образів божественного й демонічного начал у романі О. Ільченка «Місто з химерами».

Роман присвячено життю одного з найвидатніших київських архітекторів, Владислава Городецького, серед витворів якого будівля Національного художнього музею України, костел Святого Миколая, караїмська кенаса, а також знаменитий «будинок з химерами», що й опиняється у центрі роману. Події твору охоплюють значний часовий період - від «будівельної лихоманки» в Києві кінця ХІХ століття до 1917 року, пореволюційних літ і смерті архітектора на чужині у 1930 році, однак художній час максимально ущільнений, зазнає численних трансформацій, визначаючись не стільки історичною хронологією, скільки прихованим, метафізичним змістом епохальних подій. Не випадково в анотації до видання роману 2010 року його названо «метафізично правдивим». Це спричинює задану автором багаторівневість тексту, що слугує образною проекцією свідомості творчої людини, позначеної складною взаємодією вольових інтенцій і підсвідомих порухів, осмисленням історичних колізій та не завжди ясним осягненням їх метаісторичної, духовної сутності.

Художня структура твору моделюється завдяки кільком базовим змістовим рівням, що, у свою чергу, засновані на низці архетипних образів і мотивів. «Зовнішній», подієвий план репрезентований двома часовими 
площинами: життям Городецького і детективною лінією - культурологічним дослідженням, яке проводять двоє київських студентів, захоплені постаттю архітектора. Цей сюжетний рівень характеризується певною схематичністю, свідомим ущільненням художнього часу, про яке йшлося раніше. Відповідно, і хронологія як така перетворюється тут на певну умовність - вона потрібна остільки, оскільки відображує залежність людини від явищ вищого, надприродного, порядку. Це стосується як художньої біографії Городецького, так і лінії студентів-дослідників, що функціонально зводиться до означення «умовно-теперішнього» часу, з відстані якого обсервується життя і творчість митця. Другий план, співвідносний із потойбіччям, представлений мотивами віщого сну, осквернення храму i будинку, цілою низкою символічних образів. Він уводить вимір вічності, позачасовості, що, складно корелюючи 3 відображеним у першому плані часовим плином, апелює до духовних констант, репрезентованих різними культурними системами (наприклад, християнською символікою і язичницькими образами з віщування шамана). Нарешті, третій план становить найвищий рівень абстракції, представлений геометричними фігурами, що асоціюються 3 вищою закономірністю, яка існує незалежно від волі людей, хоч і втілюється за їх посередництва. Цей план співвідноситься 3 «анатомією» міста, дозволяючи трактувати його як живий організм, де розташування будинків, сакральні i профанні зони зумовлюють історичні зрушення, а, відповідно, і людські долі. Така складна будова порівняно невеликого за обсягом твору реалізується через постійне взаємонакладання цих сюжетних і образних матриць, складну взаємодію їх структурних елементів. Між усіма названими планами немає неперехідних меж. Так, зовнішній, подієвий, план містить цілу систему образних вузлівпереходів, які пов'язують його 3 планом метафізичним, а абстрактна символіка геометричних фігур, що втілюють космічний порядок, оприявнена в тексті через буденний елемент - стару карту міста.

Структуротворчим у романі $\epsilon$ мотив віщого сну, значущий для всіх світових культур. Так, у Біблії сон посилається людині для відкриття волі Божої, а отже, має пророче значення. Давні єгиптяни та представники інших древніх цивілізацій трактували сон як мандри душі в іншому світі. К. Г. Юнг вважає, що в основі людських снів лежать архетипи, «сталі мотиви, котрі виявляються у фантазіях, сновидіннях, маренні та галюцинаціях сучасної людини» $[7,18]$. Символ у сновидінні, за його теорією, належить до мотивів міфологічного плану i може бути прочитаний як притча. Сон у романі О. Ільченка є віщим, тобто зберігає метафізичне значення, яке надавалося йому в духовних традиціях різних народів, і водночас постає певним кодом, що образно репрезентує основні психологічні колізії існування митця. Саме завдяки прийому сновидіння до художньої структури твору вводяться основні символічні та смислові домінанти, такі як храм, змій, звір, кров, золото, а також провідні мотиви (осквернення дому, вигнання з храму / раю).

Роман відкривається сновидою сценою в костелі: діти, хлопчик і дівчинка, збираються прийняти таїнство шлюбу, проте суворий ксьондз виганяє їх із 
храму. Цей же сон вводить образ дому, що постає у вигляді панського будинку, віддаленого від костелу, і мотив таємниці, що інтерпретується як занурення в туман, неможливість бачити (прокидаючись, герой не може усвідомити, де він, переживає миттєвий стан загубленості в часі). Така трансформація часу, загалом притаманна художній структурі роману, надалі витворює особливу атмосферу екзистенційної невизначеності (сцена марень немолодого архітектора, в яких минулі роки постають у вигляді кривавого полювання, вбивства тварин).

Варто зауважити, що сни на початку твору витримані в ключі народної символіки, хоч і належать представникам міської культури - Владиславу Городецькому і його дружині Корнелії: весілля і втрачений зуб уві сні, за народними уявленнями, символізують смерть. У реальному, подієвому, плані твору цим символам відповідає загибель молодого робітника на будівництві костелу. Пророчий характер сновидінь увиразнюється тим, що і Владислав, i Корнелія бачать уві сні одну й ту саму сцену. Мотив вигнання 3 раю, на початку роману представлений сценою вінчання в порожньому костелі, наприкінці твору набуває суто біблійних рис: духовне відчуження подружжя втілюється у сновидній ситуації розділення чоловіка i дружини змієм. «Емігрантські» сни Городецького, позначені апокаліптичною символікою, наближаються до жанру видіння: «Внизу в прірві змій огорнув гору кільцем огидного тулуба. Він підняв голову, роззявив пащу, ладний поглинути світмісто. А вгорі над містом янголи сурмлять у сурму, провіщаючи кінець світу, й поволі згортають звиток неба» [3, 150]. Сни немолодого Городецького чи не найкраще відображують умовність категорії часу в художній структурі твору. Події, позбавлені часових зв’язків, поєднуються за калейдоскопічним, колажним принципом: архітектор бачить у своїх мареннях замах на папу Іоанна Павла II (явний вихід за межі сюжетної компетенції героя, що, як і епізод «спільного» сну подружжя, натякає на метафізичну мотивацію подій), потім - криваву сцену в опері, де терорист Богров стріляє в Столипіна, своє африканське сафарі й убивство жирафа (виразний інтертекстуальний перегук iз творчістю М. Гумільова, який з’являється в одному з епізодів роману). Всі ці сцени об'єднує мотив крові, намічений вже в перших розділах.

Віщий сон, як уже зазначалося, уводить до художньої структури твору образи символічного, вищого, порівняно 3 «буденним» рівнем, порядку. Передусім, це - константи храму, будинку і міста. Дві перші домінанти постають вже в першому сновидінні Городецького, набуваючи ознак лейтмотивів. Справді, надалі основні колізії - сюжетні, світоглядні, метафізичні - розгортатимуться навколо храму як сакрального місця осяяння, гармонії, спокути і будинку (дому) як осередку родинного і творчого життя, захищеного від сторонніх втручань. Водночас храм і будинок, включені до міського простору, де складно взаємодіють різні за вагою і призначенням локуси, визначають долю міста, що, у свою чергу, постає як модель світу і як живий організм. Сакральний символ дому в контексті міського простору зазнає десакралізації через мотив осквернення. Порушення просторової 
гармонії, глобальних принципів взаєморозташування міських локусів акцентоване у вказівках на локацію «сірого будинку»: «Будинок, зведений ним, вивищувався на пагорбі, гордо поглядаючи і на Андріївську церкву, і на Михайлівський монастир із Трьохсвятительською церквою поруч, і навіть зверхньо позирав на саму Софію Київську, оскільки сягав одного рівня з іiі розкішною дзвіницею» [3, 21]. Конфлікт будинку i храму виразно простежується вже у першому діалозі Владислава i Корнелії на балконі «дому 3 химерами»: «- Так вдало вибране місце для цього будинку - наче оглядовий майданчик. Майже вся Старокиївська ділянка перед нами.

- Майданчик для огляду, - незворушно зауважила Корнелія, - чи для обстрілу...

- Якого обстрілу?! - жахнувся Владислав. - Бог із тобою!

Бог зі мною, так, - глянула йому у вічі дружина. - А з тобою хто?» [3, 21].

Храм і будинок, перетворюючись на два протилежні полюси художнього світу, визначають ряд образних та сюжетних паралелей, що в узагальненому вигляді можуть бути представлені як наскрізне для даного твору співіснування «реальної» i метафізичної площин. Так, у першій мотив осквернення будинку реалізується через епізод пограбування, що сприймається Городецьким як лихий знак майбутньої руйнації, у другій через уже згадані віщі сни, складна символіка яких виконує роль пророцтва.

Дім як магістральний символ твору визначає специфіку його образної структури. Метафора дому переноситься й на місто та країну. Узагальнений образ Російської імперії корелює одразу з двома провідними символами твору - звіром / чудовиськом / змієм і будівлею: «Величезна, неповоротка країна, - котра, мов потворний динозавр, простяглася від Скандинавії до Чукотки, від Таймиру до Термезу, від Варшави до Владивостока, - бездарно програла війну Японії. Відтак вона немов здригалася і загрозливо рипіла, як старий дерев’яний будинок від потужними повівами близької бурі» [3; 84]. Однак історичні катаклізми обсервуються переважно через динамічний образ міста-дому-космосу, відтак десакралізація домашнього, приватного, простору розширюється до меж простору міського, історичного. Трансформації сакрального простору Києва, відтворені безпосередньо, у дусі реалістичної розповіді, або ж символічно, через сни та видіння, зумовлені багаторівневістю, полісемантичністю самого образу міста. Київ постає в іпостасях «вічного міста над Дніпром», а також «Змієвого міста», дому, організму. Багатоликість Києва виразно відчуває Городецький: «...Це непересічне місто було не таким простим, як могло видатися заїжджому купцю, прочанину, акторові антрепризи...» [3, 99]. Відчувають іiі й студентидослідники, дистанційовані від архітектора в часі: «Я знаю, де який боулінгклуб чи інтернет-кафе, - розмірковував Артем, - але тільки тепер починаю дивитися на Київ по-іншому. Мені здається, що я бачу за сучасним фасадом обриси справжнього міста...» [3, 99]

Структуротворчим у романі $є$ властивій християнській картині світу дуалізм, що поділяє буття на світлу й темну сторони. За цим принципом 
організовано образну структуру роману; постать архітектора (будівничого), який у силу свого покликання структурує зовнішній світ відповідно до власних творчих інтенцій та осяянь, перебуває на помежів”і гріховного і священного, «верхнього» i «нижнього» світів. Городецький постійно констатує свою роздвоєність, поділ власного життя на денну і нічну частину. Відтак і в романній концепції міста, яке створює Городецький разом 3 іншими архітекторами, за стратегією забудови якого уважно стежить, 3'являються два «поверхи»: місто, що уособлює день, раціональне, світле начало, і підземелля (підземні лабіринти), що постають уособленням ночі, ірраціонального, темряви. Підземний рівень Києва розгортає цілу низку асоціативних значень: інфернальне потойбіччя, підсвідомість, нарешті, глибока давнина. Його володарем $є$ змій - образ, який трактується в біблійному ключі, однак здобуває в художній структурі твору цілу низку образних аналогів, представлених різними культурними традиціями. Якщо змій $\epsilon$ символічною домінантою підземного царства, то домінантою верхнього світу, що репрезентує Київ як «Єрусалим землі Руської», постає храм. Діаметральна протилежність двох світів втілюється і в призначенні споруд, співвідносних із ними: костел та караїмська кенаса у «верхньому» світі і каналізаційні споруди - в «нижньому» (духовні й грубо-утилітарні функції, що покладаються на матеріальні об'єкти цих світів). Слід відзначити, що, попри домінування християнського трактування вічних образів, автор не обмежується цією світоглядною системою. Про це свідчить епізод камлання й пророцтва алтайського шамана, який оперує іншими, язичницькими, поняттями. Прикметно, що кожен із елементів потойбічного світу, згаданий шаманом, має відповідник у християнській традиції: Ерлік Кан, володар підземного світу, співвідноситься з дияволом, безодня Казирган - із пеклом (на матеріальному рівні цей інфернальний світ втілюється в урвищі, над яким побудовано «будинок з химерами»). Городецькому не одразу відкривається прихований зміст настанови шамана «думати про велетенську рибу Кербалик, котра тримає світ на собі»; тільки згодом він пригадує, що риба є давнім символом Ісуса Христа. Таким чином у тексті роману виявляється єдність світових духовних традицій $\mathrm{i}$ - ширше, єдність світу, створеного за єдиним для всіх принципом.

Слід відзначити, що між «верхнім» і «нижнім» світом немає неперехідних меж. У романі виразно окреслено низку вузлових образів-«переходів», завдяки яким здійснюється зв'язок між денним і нічним світами. Особливе значення у формуванні таких зв'язків належить явищу інтертекстуальності. Репрезентативним у цьому відношенні $є$ образ мавпи-макака, якого носить на плечі Городецький. Відчутним $є$ перегук із «Вечорами на хуторі поблизу Диканьки» М. Гоголя, що вводиться характеристикою, яку дає Городецькому Ольга Петрівна Косач: «Людина, котра зводить такі страшні будинки, не тільки мавпу, а й чорта за плечима носитиме!» [3, 45]. Образ мавпи, що $\epsilon$ буденним, «опобутовленим», втіленням інфернальної сутності, корелює 3 
цитатою із «Фауста» Гете, що ii наводить Городецькому архітектор Безсмертний:

Людина не всякчас діяльності радіє,

Понад усе кохає супокій:

Потрібен їй супутник ворушкий,

Щоб бісом грав і змушував до дії.

Як своєрідний знак потойбіччя сприймається й вірш Миколи Гумільова «Носоріг». Зооморфні образи, що пронизують текст роману, передані через прийом екфразису (змалювання «будинку 3 химерами») чи згадані безпосередньо (екзотичні тварини, бачені й здобуті Городецьким під час полювання, мавпа-макак), часто постають носіями інфернальної тематики. Однак згаданий вірш М. Гумільова витворює ще складніше смислове поле. В романі акцентовано приналежність молодого поета до нового покоління митців, творчість яких сприймається представниками старшої генерації, в тому числі й Городецьким, критично, майже зверхньо. Однак і перші, і другі на зламі століть стають носіями кризової свідомості. Цю тезу під час розмови 3 Городецьким висловлює Безсмертний. Головний герой, прагнучи збагнути справжню природу своїх душевних порухів, вражений твором Гумільова, почутим на поетичному вечорі: «Не шукай собі спасіння... - повторював Городецький, - не шукай... навіть тікаючи, навіть ховаючись. Це він про що? Про Африку? А може, ці поети й справді прозрівають глибше, ніж враження від мавп і носорогів? [...] Час їхати подалі від цього міста, від його будинків, його потойбіччя?» $[3,117-118]$

«Агентами» інфернального потойбіччя в денному світі виступають головним чином скульптурні зображення, що оздоблюють архітектурні споруди. Цей пласт образів моделюється завдяки прийому екфразису. Формування міського простору, покладене на архітекторів, сприймається як матеріалізація велінь змія, володаря «нижнього» світу, у світі «верхньому». Таким чином, зв'язок цих двох рівнів світобудови реалізується за допомогою інтертекстуальності, зооморфних та екфрастичних (скульптурних) образів.

Попри домінування дуалістичної картини світу, репрезентованої християнською символікою та язичницькою образністю питомої релігії Алтаю, в романі неодноразово висловлено концепцію всеєдності світу, де світле й темне начала тільки доповнюють одне одного, щоправда, ці тези вкладаються у вуста Хвойки, який підходить до поставлених Городецьким питань iз позицій ученого-культуролога, та Безсмертного, який прагне переконати себе і співрозмовника в тому, що їх нічні марення - це тільки гра фантазії. Варіативність трактування образу змія відображує його смислову багатовимірність у світових культурних традиціях. Змій у тому чи іншому вигляді постає в багатьох сюжетах українського фольклору. Так, у космогонічних міфах він асоціюється 3 творцем-деміургом або 3 різними

\footnotetext{
${ }^{1}$ Переклад Миколи Лукаша.
} 
частинами Всесвіту; у міфах близнюкового культу репрезентує одразу два світи - «верхній», де реалізується його зв'язок зі стихією повітря, і «нижній», де він постає як володар вогню (звідси, очевидно, походить властиве християнству ототожнення змія з дияволом). Християнським за своєю суттю $\epsilon$ мотив спокуси, що домінує у снах Городецького. Майнові статки архітектора й успіх на полюванні в художній структурі твору трактуються як винагорода, що іiі отримує будівничий за виконання задуму змія. Кров i золото перетворюються на лейтмотиви денного існування Городецького, дві субстанції, що символізують життя і смерть, однаково знецінені в антисвіті, створити який прагне змій («золото від живих і кров від убієнних» $[3,28]$ ). Варто зазначити, що мотив убивства / полювання в даному випадку трактується дуже широко, урівнюючи тварин, людей, зрештою, простір, у якому існують ті й інші (убивство звірів; сновидні епізоди замахів на Папу Римського та Столипіна; плюндрування й знищення звичного міського простору під час воєнного лихоліття). Поступове нагромадження інфернальних образів відображує перетворення космосу на хаос, де стираються межі між сном і дійсністю, а сам мисливець перетворюється на здобич.

Особлива роль, як уже зазначалося, належить у творі зооморфним образам. Багатозначність образу звіра в найширшому його прочитанні відображена вже в мальовничому описі «будинку 3 химерами», представленому через діалог студентів-дослідників. Юнаки помічають, що «всі зображення на ньому можна поділити на дві групи. Перші - цілком реальні зображення ящірок, жаб, голів косуль, носорогів, слонів... [...] Друга група зображень - абсолютно фантастичні істоти» [3, 64]. Постійне звернення автора до зооморфних образів пояснюється особливостями біографії самого Городецького - мисливця й мандрівника, проте водночас ці образи, як і низка інших, виявляють багатозначність, аж до виразно інфернального, змісту. Звір-жертва значною мірою асоціюється з самим архітектором, що зазнає втручання у власне життя сил, природи й задумів яких не може збагнути. Водночас змій, якому всупереч своїй волі служить Городецький, ототожнюється 3 апокаліптичним звіром [3, 27]. Слід зауважити, що символіка снів Городецького, як і вся образна система твору, прямує до поступового ускладнення: так, першій появі змія у сні архітектора передує також сновидна сцена полювання, що зазнає складної метафоризації, уподібнюючись до видіння. Хижак (звір), полювання на якого змальовано в реалістичному ключі, перетворюється на інфернальну істоту (змія), що виникає 3 води, викликаючи прямі асоціації з текстом Апокаліпсису, видінням пророка Іоанна Богослова. Слід зазначити, що поява змія, як і перший сон Городецького (вінчання в костелі), пов'язаний iз неспроможністю для сновидця бачити, тобто має символічне забарвлення таємничості, натякає на закриті від людини сфери буття.

Третій, найбільш абстрактний, образний рівень твору, як уже зазначалося, становлять геометричні й цифрові символи, передусім трійка, асоційована 3 
трикутником, i четвірка. Реальний міський простір, репрезентований архітектурними будівлями, піддано подвійному абстрагуванню у топографічному зображенні й геометричній фігурі, що виконує містичну функцію. Водночас, саме через геометричні символи Київ представлено в антропоморфному ключі, як живий організм, наділений буттям на різних рівнях: наземному, денному, і підземному, нічному, демонічному. Місто наділене анатомічними особливостями - це його зовнішній вигляд, його будова, взаємозв'язок основних містоутворюючих елементів, серед яких виділяються географічне положення і архітектурний план.

Трикутник, центральний геометричний символ твору, виявляє множинність значень у світових духовних традиціях, найчастіше втілюючи божественне (Свята Трійця у християнстві; Шива, Вішну і Брахма в індуїзмі; Озиріс, Ісида і Гор у релігії Давнього Єгипту). Число «три» постає моделлю Всесвіту, втілюючи верх, середину і низ у впорядкованому Космосі; у піфагорійській системі, відповідно, це число символізувало початок, існування та кінець світу. Значення числа пов'язувалося із породженням, творенням нового життя: «Існування двох /батька i матері/ майже невідворотно веде до появи третього /сина/... За словами Лао-дзи: “...одне народжує двох, двоє народжують третього; троє народжує десять тисяч речей /тобто увесь світ/". Тому тріада володіє здатністю розв'язувати конфлікт, створений дуалізмом... Вона символізує творення духу із матерії, активного із пасивного» $[4,521]$. О. Ільченко переосмислює цей символ, уводячи образ «диявольського» трикутника, утворений трьома будинками із зображеннями демонів, що замикає у собі «сакральне серце» міста - Софію Київську. Таким чином, геометричний символ трикутника дозволяє ввести ще один план сприйняття міського простору - антропологічний, оснований на аналогії між містом і людським тілом. Ототожнення храму і серця, погляд на місто як на живий організм і храм як його духовне осердя закономірно постає на основі питомої для українства «філософії серця», репрезентованої передусім вченням Григорія Сковороди: «Серце як сукупність почуттів, бажань, прагнення, як “осердя” людини і є тією силою, “в которой единственно сотоит жизнь и живот наш”. Серце, передусім, Г. Сковорода розглядає як духовну субстанцію, що $\epsilon$ основою людського буття i джерелом життєдіяльності людини. Оскільки духовну субстанцію і джерело діяльності утворює в людині Бог, Г. Сковорода часто ототожнює серце з Богом або Словом Божим. Це утворює метафізичний аспект розуміння серця» $[1,97]$. Якщо храм пов'язаний із духовним центром людської істоти, у фізичному плані втіленим через серце, то міська каналізація, де мешкає змій, представляє людський «низ», витіснені інстинкти, підсвідомі порухи, агресію. Зведення «диявольських» будинків в антропоморфному міському просторі асоціюється 3 грубим порушенням природних законів функціонування здорового організму. Отже, в романі О. Ільченка переосмислений в негативному ключі символ трикутника разом із мотивами вигнання із сакрального центру, осквернення дому, вбивства творить картину 
«перевернутого» світу, в якому втрачена гармонія. Таке світовідчуття зумовлює особливу динаміку макрообразу міста, який розвивається від ідилічних замальовок, величних панорам до моторошної картини запустіння, що постає в одному з видінь Городецького, i, нарешті, - апокаліптичної візії.

Метафізичний зміст діяльності архітектора реалізується також через число «чотири». Виступаючи своєрідним відповідником дуалістичної картини дійсності, властивої християнському світосприйняттю, в художній структурі твору воно втілює рівновагу. Подібні міркування висловлював стосовно цього числового символу К. Г. Юнг: догма тілесного вознесіння Діви Марії пояснюється ним як прагнення увести до Святої Трійці жіночий елемент, доповнивши символічний трикутник, що відповідає їй, і утворивши інший геометричний символ - квадрат, пропорційний і цілісний за своєю формою. Як дізнається Городецький з віщування шамана, метою життя для нього має стати створення «благодатної четвірки» архітектурних споруд, що нейтралізує дію страшного трикутника і поверне світові й життю архітектора втрачену гармонію. Прикметно, що ця четвірка все-таки відповідає триєдності світу. Тут доречно пригадати біблійну традицію поділу людської природи на тіло, душу і дух. «Благодатну четвірку» утворюють храми різних конфесій, останній $з$ яких Городецький так і не встиг звести: караїмська кенаса, католицький костел, православна церква і мусульманська мечеть.

Таким чином, попри розмаїтість культурних пластів, задіяних у моделюванні художнього світу твору, підкреслену мозаїчність і складність його сюжетної будови, суміщення різних часових планів, у романі вибудовується чітка світоглядна вертикаль, грунтована на поступовому сходженні від буденного плану, представленого динамічним міським простором із підкресленою увагою до побутових деталей, відтворення окремих локусів та їх взаєморозташування, до символічних планів, що характеризуються дедалі вищим рівнем образної абстрактності - складної символіки, яка демонструє культурну полісемію у втіленні одних і тих самих релігійних та філософських констант, i, нарешті, символіки чисел та геометричних фігур, що відповідають космічному закону і узагальнюють множинність культурних інтерпретацій добра i зла. Потужний історикокультурний контекст дає підстави трактувати божественну і демонологічну символіку як образне втілення історичних катаклізмів, у яких талант i людські якості митця проходять перевірку на життєздатність.

\section{ЛIТЕРАТУРА}

1. Горський В. С. Історія української філософії: [курс лекцій] / В. С. Горський. - К.: Наукова думка, 1996. - 287с.

2. Дмитренко М. Символіка снів / М. Дмитренко. - К., 1992. - 84 с. 3. Ільченко Олесь. Місто з химерами: [текст] / Олесь Ільченко. - К.: Грані-Т, 2010. - 160c.

4. Керлот Х.Э. Словарь символов / Хуан Эдуардо Керлот. - М., 1996. 598 c. 
5. Лотман Ю.М. Внутри мыслящих миров: Человек - текст - семиосфера - история / Ю.М. Лотман. - М.: Языки русской культуры. - М., 1996. - 464 с.

6. Потебня А. А. Символ и миф в народной культуре / А. А. Потебня. M., 2000. -184 c.

7. Юнг К.Г. Архетипи і колективне несвідоме / Карл Густав Юнг. - Львів: Астролябія, 2013. - 587 с.

В статье исследуется роман Олеся Ильченко «Дом с химерами» с точки зрения репрезентации в нем понятий божественного и демонического. Художественная структура произведения моделируется посредством нескольких смысловых уровней, основанных на ряде образов и мотивов, которые становятся предметом специильного интереса в работе. Освещается специфика художественной трансформации культурных констант храма, дома, города, а также числовой символики; исследуется характер метафоризации городского пространства как дома, космоса, организма.

Ключевые слова: художественная структура, символ, архетип, культура.

In the article Oles Ilchenko's novel "The city with chimeras" is investigated in terms of divine and demonic categories' offered in the text. The artistic structure of the novel is designed with several semantic levels based on the row of archetypical images and motives which became the subjects of special interest in this work. The artistic transformation of cultural constants of temple, home, city and digital symbolics are explained in the article. The metaphorical comprehension of city space as home, universe and organism are investigated. The special attention is paid to the conception of history that demonstrates the connection of human existence and metaphysical sphere. The author makes the system of textual transitions between these levels of novel's artistic structure. There are intertextual phenomena, the images of buildings and animals.

Key words: artistic structure, symbol, archetype, culture. 